INTERNATIONAL JOURNAL OF RESEARCHES IN BIOSCIENCES, AGRICULTURE AND TECHNOLOGY (C) VISHWASHANTI MULTIPURPOSE SOCIETY (Global Peace Multipurpose Society) R. No. MH-659/13(N) www.ijrbat.in

\title{
SEASONAL VARIATIONS IN PHYSICO-CHEMICAL CHARACTERISTICS OF CHULBAND RIVER - SOUNDAD, GONDIA DISTRICT, (M.S.) INDIA.
}

\author{
Prashant C. Shahare and K. J. Cherian' \\ D. B. Science College, Gondia. India. \\ ${ }^{1}$ Department of Botany, Sindhu Mahavidyalaya, Nagpur, India. \\ prashant_26184@rediffmail.com.
}

\begin{abstract}
:
Seasonal Variations in physico-chemical parameters were carried out during the two years Feb.2010 to Jan-2012 from Chulband River at Soundad in Gondia District. The various parameters such as Velocity, Temperature, Turbidity, Transparency, TDS, TSS, TS, pH, DO, BOD, $\mathrm{CO}_{2}$, Hardness, Calcium, Magnesium, Chloride and Phosphorus were analysed. The results revealed that there was significant alterations in the physicochemical parameters and some of the parameters were in the normal range and Turbidity, DO, BOD and Phosphorus results are indicated not good quality of river water. Turbidity of rainy and summer seasons are exceeding 11 to 14 times as per WHO and BIS standard. DO, BOD and Phosphorus results were exceed the limit of WHO and ISI. Our findings highlighted the deterioration of water quality in the river due to industrialization, discharge of domestic, agricultural and human activities. To improve quality of water there should be continuous monitoring of pollution level and maintain the favourable conditions essential for aquatic organism's survival, growth and reproduction.

Keywords: Seasonal Variations, Physico-chemical parameters, Chulband River, Soundad.
\end{abstract}

\section{Introduction}

Freshwater ecosystems are considered as one of the most important natural resources for the survivability of all the living organisms of the biosphere. Rivers have always been the most important freshwater resources along the banks of which our ancient civilizations have flourished and most developmental activities are still dependent upon them. River water finds multiple uses in every sector of development like agriculture, industry, transportation, aquaculture, public water supply etc (Shiddamallayya and Pratima, 2008). Water quality has direct relation with aquatic productivity (Moses, 1983; Shrestha and Kazama, 2003). Aquatic organisms need a healthy environment. Maximum productivity depends on optimum level of physicochemical parameters (Sadia et al., 2013). Biological assessment is a useful alternative for evaluating the ecological quality of aquatic ecosystems since biological communities integrate the environmental effects of water chemistry (Shahare, 2016). Assessment of riverine water was carried out by assessment of its physicochemical parameters (Rao and Vaidyanadhan, 1979; Muniyan and Ambedkar, 2011).

Cherian and Shahare (2011) studied earlier on "Pollution, a threat to conservation of biodiversity in fresh water body of Chulband River, Gondia dist., Maharashtra". Shahare and Cherian (2012) worked on "Study of Cyanophycean diversity at Chulband Dam, Gondia Dist. (M.S.) India”. Shahare (2015) studied Assessment of Physico-Chemical parameters of Chulband dam in Gondia District. (MS), INDIA. Shahare (2016) earlier studied on Physico-Chemical analysis of Chulband River at Dodake-Jambhali, Gondia District. (MS), INDIA. Chulband River makes its origin from various small and large streams scattered in the forest hilly areas of eastern part of Gondia district. It flows in the Jambhali forest area for few $\mathrm{kms}$ and then enter in the Chulband dam towards Chulband River at Soundad which the present study was undertaken.

\section{Materials and Methods}

The present investigation at Soundad location is (Latitude. 21 04"47.58' N \& Longitude. 8006"19.30’ E) and Fig. 1.

\section{Sampling and Analysis of Water}

The study was carried for a period of 2 years (February 2010 to January 2012). Monthly data was collected, but results were represented average mean season wise. The water samples were collected between 9.00 AM to $11.00 \mathrm{AM}$ from sampling site in pre-cleaned, BOD bottle, sterilized polythene containers of one litre capacity and brought to the laboratory for the analysis of various physicochemical parameters. Water velocity, temperature, $\mathrm{pH}$, Turbidity and Transparency, were recorded immediately on the spot. The following physico-chemical parameters were analyzed TDS, TSS, TS, pH, DO, BOD, $\mathrm{CO}_{2}$, Hardness, Calcium, Magnesium, Chloride and Phosphorous. The parameters were analysed by using standard procedures described in APHA (1998), IAAB (2006) and Water Velocity (http://www.geography-site.co.uk) method. 


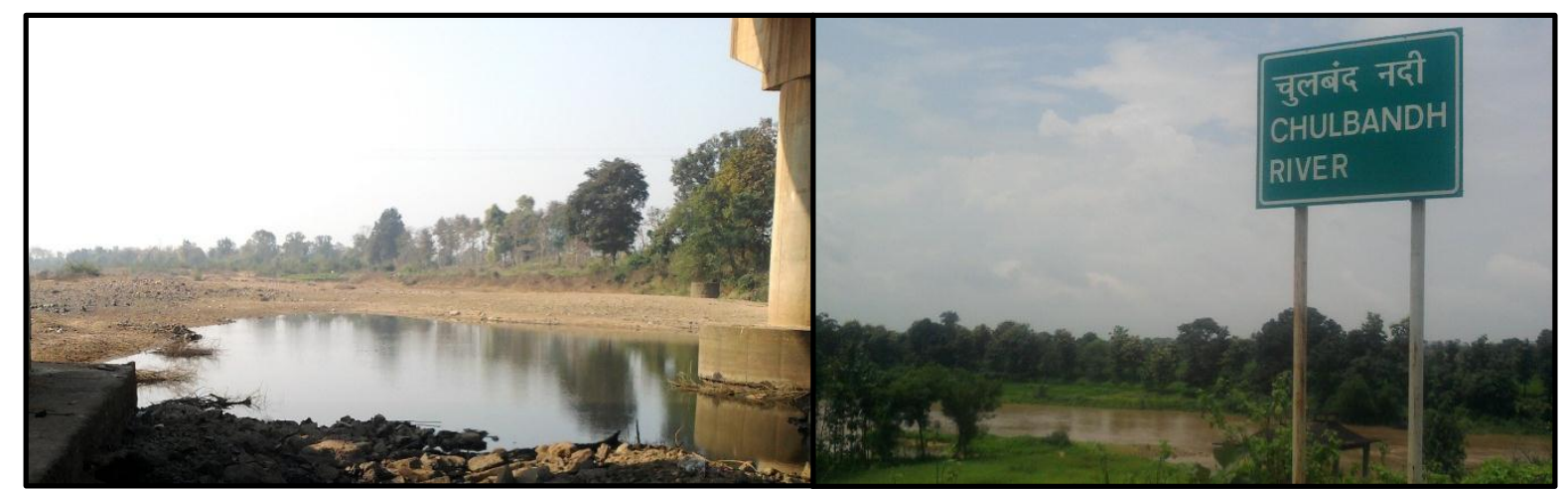

Fig.I Chulband River, Soundad, Gondia district. (MS.)

\section{Result and Discussion:}

In the present investigation, considerable variation in average mean seasonwise physicochemical parameters is presented in Table no.1.

Velocity: Water stream average mean velocity of the seasonwise summer, rainy and winter are $0.0,0.56$ and $0.10 \mathrm{~m} / \mathrm{sec}$ respectively (Graph.1). The stream velocity was lowest at summer season $(0.0 \mathrm{~m} / \mathrm{s})$ stagnant water and highest at rainy season $(0.56 \mathrm{~m} / \mathrm{sec})$ with significant variation. Seasonal variation in water current has been reported in streams of Palani hills (Sivaramkhrishhnan and Venkataraman, 1990).

Temperature: Hutchinson (1957) suggested that meteorological conditions are responsible for seasonal changes in temperature. In the present study average mean water temperature ranged from minimum $24.88^{\circ} \mathrm{C}$ in winter season to the maximum $29.50^{\circ} \mathrm{C}$ in rainy season (Graph.2) similar reports were observed by Salve and Hiware (2008). The water temperature depends on geographical location and meteorological condition.

Turbidity: The average mean turbidity value for winter season, summer and rainy season are Negligible, 118.00 and 146.50 respectively was recorded (Graph.3). As per WHO and BIS standard (10 NTU) our results of rainy and summer seasons are exceeding 11 to 14 times. Turbidity is a measure of water clarity how much the material suspended in water decreases the passage of light through the water. Turbidity was higher which was because of rains bringing the sediments from the adjoining areas and due to turbulent flow which stirred up the nonliving matter like silt and sand at the bottom of the river during rainy seasons. However, other seasons may affects due to low level of water content and high anthropogenic activities along the river water.

Transparency: For transparency, high seasonal variation was found in the studied location. The descending trend of transparency is found in the present study as winter > rainy $>$ summer. The average mean value for winter season, rainy and summer are 29.98, 20.79 and $16.32 \mathrm{~cm}$ respectively. (Graph.4).

TDS (Total Dissolved Solids): Total Dissolved Solids indicates the salinity behaviour of river water. The mean average TDS value during the period of investigation was ranged between $172.63 \mathrm{mg} / \mathrm{L}$ winter season and $260.50 \mathrm{mg} / \mathrm{L}$ in rainy season (Graph.5). The higher TDS was depends on the natural sources, location, and geology of the river. Similar trend was reported by Shinde et al., (2010) in Savangi dam, district Aurangabad.

TSS (Total Suspended Solids): The average mean Total Suspended Solids (TSS) of the water samples was minimum $101.00 \mathrm{mg} / 1$ at winter season and maximum $125.13 \mathrm{mg} / 1$ at the rainy season (Graph.6).

TS (Total Solids): TS ranged between average mean $273.63 \mathrm{mg} / 1$ in winter season and $385.63 \mathrm{mg} / 1$ in rainy season. (Graph.7). TS of the water causes the reduction in light penetration, ecological balance and ultimately affects the water quality. It may affect the osmotic regulation of aquatic fauna.

pH: The maximum mean average $\mathrm{pH}$ was recorded in summer 7.43 and minimum was in rainy season 7.00. (Graph.8). Similar reports were observed by Bobdey (2002) had recorded $\mathrm{pH}$ values between 7.0 to 8.50 in the river Wainganga at Pauni, Maharashtra.

DO (Dissolved Oxygen): DO in water bodies depends on various factors like climatic conditions, partial pressure of gases, dissolved salts, stream velocity, relative solubility, photosynthetic activity of plants, respiration by aquatic microbes, plants and animals (Zutshi and Vass, 1978). In the present investigation mean DO varied between 5.63 $\mathrm{mg} / \mathrm{L}$ in rainy season, $6.88 \mathrm{mg} / \mathrm{L}$ in summer season and $6.44 \mathrm{mg} / \mathrm{L}$ in winter season (Graph.9). The WHO standard recommended DO is $5 \mathrm{mg} / 1$ while ISI $3 \mathrm{mg} / 1$. Our results were exceed the limit of WHO and ISI. 
BOD (Biochemical Oxygen Demand): BOD is an important parameter that indicates the magnitude of water pollution by oxidizable organic matter. The main sources of organic pollution include untreated domestic sewage, agricultural runoff, and containing residual fertilizers. In the present research seasonal

Table No.1: Seasonal variations in physico-chemical parameters of, Chulband River, Soundad (M.S) India.

(During Feb. 2010 - Jan. 2012)

\begin{tabular}{lcccc}
\hline Parameters & Range & Summer & Rainy & Winter \\
\hline Velocity & $0.0-1.157$ & 0.0 & $0.56 \pm 0.16$ & $0.10 \pm 0.08$ \\
Temperature & $20-32$ & $28.13 \pm 1.47$ & $29.50 \pm 0.63$ & $24.88 \pm 1.32$ \\
Turbidity & $112-360$ & $118.00 \pm 27.39$ & $146.50 \pm 49.24$ & 0 \\
Transparency & $6.35-42.84$ & $16.32 \pm 1.48$ & $20.79 \pm 5.21$ & $29.98 \pm 1.39$ \\
TDS & $118-302$ & $221.63 \pm 7.65$ & $260.50 \pm 12.50$ & $172.63 \pm 13.32$ \\
TSS & $59-164$ & $107.50 \pm 8.55$ & $125.13 \pm 10.52$ & $101.00 \pm 9.09$ \\
TS & $228-437$ & $329.13 \pm 13.92$ & $385.63 \pm 14.72$ & $273.63 \pm 11.62$ \\
pH & $6.4-8$ & $7.43 \pm 0.13$ & $7.00 \pm 0.13$ & $7.29 \pm 0.04$ \\
DO & $5.1-8.3$ & $6.88 \pm 0.47$ & $5.63 \pm 0.11$ & $6.44 \pm 0.28$ \\
BOD & $2.3-16.7$ & $5.14 \pm 0.67$ & $7.84 \pm 1.06$ & $11.88 \pm 1.09$ \\
CO & $4.7-14.6$ & $13.34 \pm 0.37$ & $7.44 \pm 0.83$ & $6.76 \pm 1.00$ \\
Hardness & $37.4-144.28$ & $78.30 \pm 5.28$ & $71.10 \pm 14.07$ & $79.78 \pm 5.51$ \\
Calcium & $11.22-60.92$ & $28.63 \pm 3.42$ & $28.35 \pm 6.97$ & $25.91 \pm 2.34$ \\
Magnesium & $12-83.36$ & $49.68 \pm 5.40$ & $42.74 \pm 8.09$ & $53.88 \pm 5.15$ \\
Chloride & $30.5-81.65$ & $49.10 \pm 2.94$ & $45.23 \pm 7.71$ & $38.98 \pm 0.75$ \\
Phosphorus & $0.5-2.1$ & $1.15 \pm 0.17$ & $1.46 \pm 0.13$ & $1.33 \pm 0.14$ \\
\hline
\end{tabular}
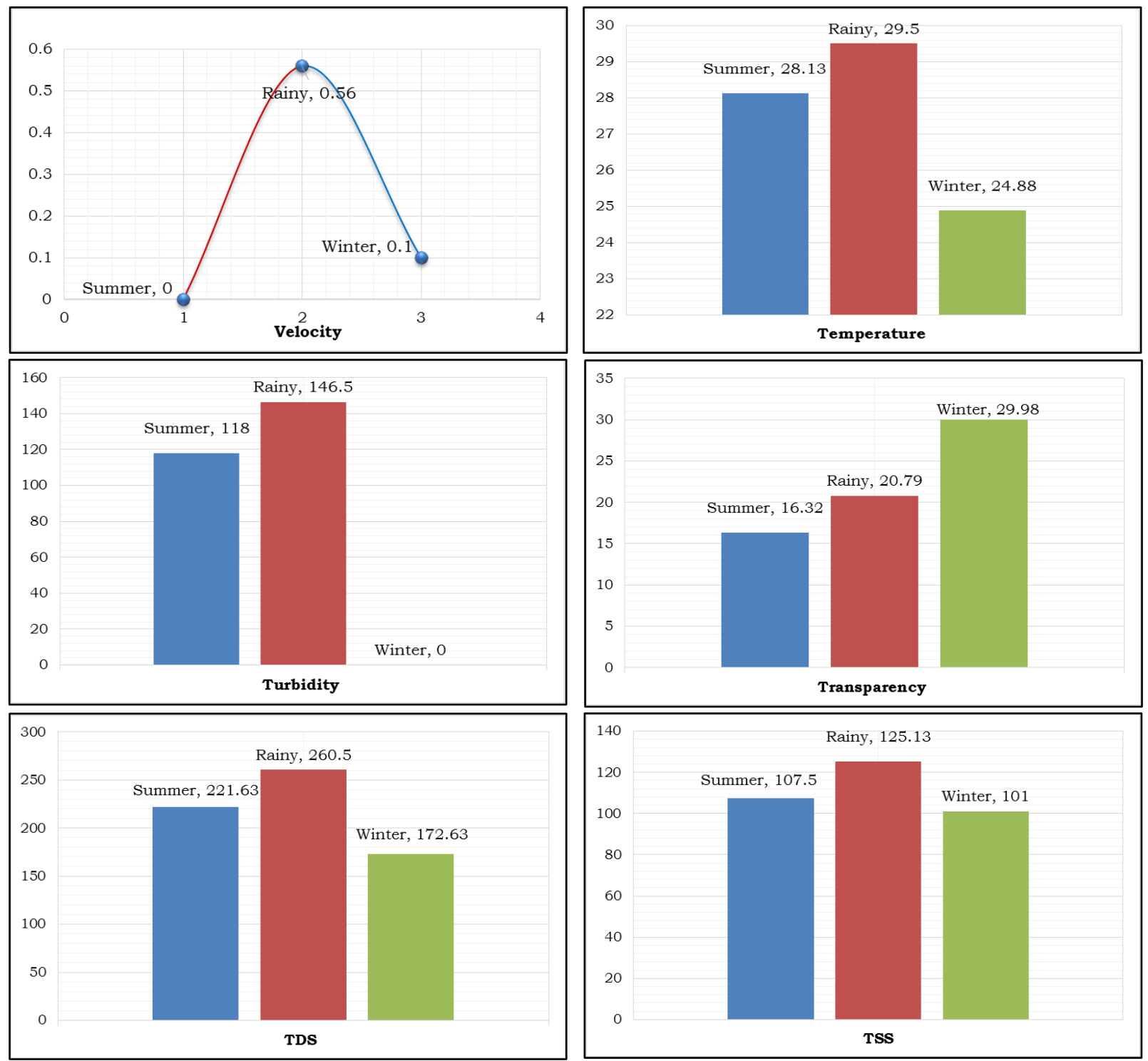

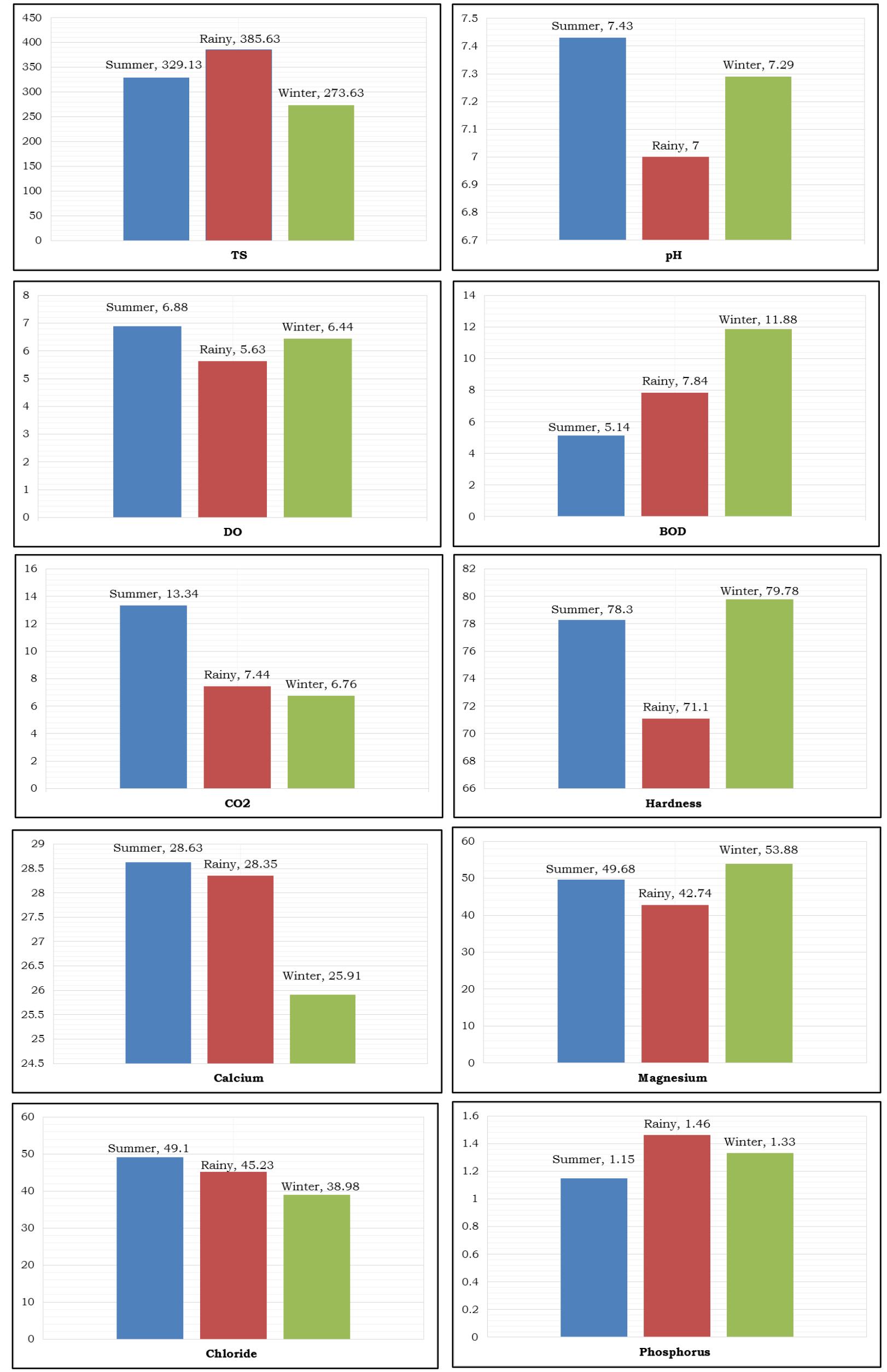

$\underset{\substack{\infty \\ 0 \\ 0 \\ 0}}{0}$ 
$\mathrm{CO}_{2}$ (Carbon Dioxide): The $\mathrm{CO}_{2}$ of the water sample varied between $6.76 \mathrm{mg} / 1$ in winter season, and $13.34 \mathrm{mg} / 1$ in summer season. (Graph.11). The $\mathrm{CO}_{2}$ level mostly governs by the available algae as well as diffusion through atmospheric air.

Hardness: Hardness was found to fluctuate between $71.10 \mathrm{mg} / 1$ in rainy season and 79.78 $\mathrm{mg} / 1$ in winter season (Graph.12). Hardness of water is not a pollution parameters but indicating water quality mainly in terms of $\mathrm{Ca}++$ and $\mathrm{Mg}++$ expressed as $\mathrm{CaCO}_{3}$. The increase in hardness can be attributed to the decrease in water volume and increase in the rate of evaporation at high temperature (Kaur and Sharma, 2001)

Calcium: The average mean Calcium of the water samples was minimum $25.91 \mathrm{mg} / 1$ at winter season and maximum $28.63 \mathrm{mg} / 1$ at the rainy season with similarly $28.35 \mathrm{mg} / 1$ at the summer season (Graph.13). The presence of calcium in the water is more likely in the form of carbonate, which is also indicated by high values of hardness in water samples.

Magnesium: Magnesium is an essential element for all living organisms as it takes part in chlorophyll biosynthesis and enzymatic transformation (Weztel, 1975). The average mean Magnesium of the water sample varied between $42.74 \mathrm{mg} / 1$ in rainy season and 53.88 $\mathrm{mg} / 1$ in winter season. (Graph.14).

Chloride: In the present study, $\mathrm{Cl}^{-}$ concentration varied from 38.98 to 49.15 $\mathrm{mg} / \mathrm{L}$, minimum in winter and maximum in summer (Graph.15). Similar reports were observed by Shinde et al., (2010) in HarsoolSavangi dam, (M.S) India. (During. High value of chloride and calcium in drinking water are generally not harmful to human being but high concentration of chloride may affects a person who already suffers from diseases of heart and kidney.

Phosphorus: Phosphorus is the essential elements for increase in productivity of biological produce (Hutchinson, 1957). The Phosphorus of the water sample varied between $1.15 \mathrm{mg} / 1$ in summer season and 1.46 $\mathrm{mg} / 1$ in rainy season (Graph.16). WHO and ISI recommended Phosphorus level as 0.1 to 1.0 $\mathrm{mg} / 1$ for drinking water. Our results were exceed the limit of WHO and ISI.

\section{Conclusion:}

During study, water sample from of Chulband River, Soundad, Gondia district (M.S) were collected for the period of 2 years (Feb 2010 to Jan 2012) and season wise analysis of various physico-chemical parameters had been carried out. The results revealed that there was significant alterations in the physicochemical parameters and some of the parameters were in the normal range and Turbidity, DO, BOD and Phosphorus results are indicated not good quality of river water. Our findings highlighted the deterioration of water quality in the river due to industrialization, discharge of domestic, agricultural and human activities. To improve quality of water there should be continuous monitoring of pollution level and maintain the favourable conditions essential for aquatic organism's survival, growth and reproduction.

\section{References:}

APHA (1998). Standard Methods for the Examination of Water and Waste Water : 20th Edn., Washington D.C., U.S.A.

Bobdey, A.D. (2002). Impact of human activities and domestic wastes: Appraisal of potable water quality of river Wainganga Dist. Bhandara, Ph.D. Thesis, submitted to North Maharashtra University, Jalgaon, Maharashtra.

Cherian K. J. and Shahare P. C. (2011). "Pollution, a threat to conservation of biodiversity in fresh water body of Chulband river, Gondia dist., Maharashtra" Essence, Volume II No. 2 (70 78).

\section{http://www.geography-site.co.uk}

Hutchinson, G. E., (1957). A treatise on limnology, Vol. 1 Geography, Physics and Chemistry. John Willey and Sons, Inc. New York 1015.

IAAB (2006). (Indian Association of Aquatic Biologists) manual.

ISI. (1973). Indian standard methods for sampling and test (physical and chemical) for water used in industry. Manak Bhawan: Indian Standard Institute.

Kaur, H. and Sharma, I. D. (2001). Hydrobiological studies on river Basantar, Samba, Jammu (Jammu and Kashmir). J. Aqua. Biol. (16) 1: 41-44.

Moses B.S. (1983). Introduction to Tropical Fisheries. University Press, Ibadan,; pp. 105.

Muniyan M and Ambedkar G. (2011). Seasonal Variations in Physicochemical Parameters of Water Collected from Kedilam River, at Visoor Cuddalore District, Tamil Nadu, India International Journal of Environmental Biology; 1(2): 15-18. 
Rao KN and Vaidyanadhan R; (1979). Evolution of coastal land forms in the Krishna delta, Front, India, Trans. Inst. Indian. Geogr, $1(25-32)$.

Sadia A, Feroza HW, Imran $Q$, Muhammad Hamid SW, Tirmizi SA, Muhammad AQ; (2013). Monitoring of anthropogenic influences on underground and surface water quality of Indus River at district Mianwali-Pakistan. Turk. J. Biochem. 38(1):(25-30).

Salve, V.B. and Hiware C.J. (2008). Study on water quality of Wanprakalpa reservoir Nagpur, Near parli Vaijnath. Dist. Beed, Maharashtra region, J. Aqua Biol, 21(3): (113-117).

Shahare P.C. and Cherian K.J. (2012). "Study of Cyanophycean diversity at Chulband Dam, Gondia Dist. (M.S.), India." Bionano Frontier, Special Issue-9 (128-130).

Shahare, P. C. (2015). Assessment of PhysicoChemical parameters of Chulband dam Gondia District. (MS), INDIA. I J R B A T, Vol II (7), (484488).

Shahare, P. C. (2016). Physico-Chemical analysis of Chulband River at Dodake-Jambhali, Gondia District. (MS), INDIA. I J R B A T, Vol. IV, Issue (2), (52-57).
Shiddamallayya N, and Pratima M, (2008). Impact of domestic sewage of fresh water body. J. Environ. Biol, 29, (303-308).

Shinde, S. E., Pathan, T. S., Raut, K. S., More, P. R., and Sonawane, D. L. (2010). Seasonal variations in physico-chemical characteristics of Harsool - savangi dam, district, AURANGABAD, INDIA. The Ecoscan Journal of Environmental Sci. Vol. 4 (1), (37-44).

Shrestha S, and Kazama F. (2007). Assessment of surface water quality using multivariate statistical techniques: a case study of Fuji river basin, Japan. Environ. Model. Soft. 22(4): (464475).

Sivaramkhrishhnan, K.G. and Venkataraman, K; (1990). Abundance, altitudinal distribution and Swarming of Ephemeroptera in Palani hill, South India. In: Mayflies and stoneflies (Ed.). Campbell, I.C. Kluwer, New York, (209-213).

Weztel, R. G. (1975). Primary production river ecology. Blackwell Scientific Publication, Oxford.

World Health Organization, (1993). Guidelines for drinking water quality- I, Recommendations, 2nd edn Geneva WHO.

Zutshi, D. P., and Vass, K. K., (1978). Limnological studies on Dal Lake. Chemical features. Indian J. Ecol. 5, (90-97). 